\title{
THE INCIDENCE OF SPERMATOZOA WITH MORPHOLOGICAL CHANGES IN SEMEN COLLECTED FROM CANINE EPIDIDYMIDES
}

Siedlce University of Natural Sciences and Humanities, Faculty of Agrobioengineering and Animal Husbandry, Siedlce, Poland

\begin{abstract}
The aim of the study was to analyze the incidence of spermatozoa with morphological changes in semen collected from canine epididymides. The study was conducted on five dogs with gonads obtained from them as a result of routine castration performed at a veterinary clinic. Epididymides were isolated after gonadal lavage with PBS fluid. Semen was collected by incising individual parts of the epididymis (caput, corpus, cauda) with a sterile scalpel, when placed in separate Petri dishes. Sperm morphology was prepared from the semen collected in this way. The preparations were stained with the SpermBlue method. The sperm morphology was assessed using a 100x immersion lens with a Nikon E-50i light microscope. In each preparation, the morphological structure of 200 spermatozoa was assessed, specifying the sperm cells with normal morphological structure and those with changes in their head, tail, and those with cytoplasmic droplets. Based on the performed study, it was found that there are differences in the incidence of sperm cells with morphological changes in individual sections of the epididymal duct. The largest share of spermatozoa with normal morphological structure was observed within the corpus of the epididymis. The most spermatozoa with head changes and with cytoplasmic droplets were found in semen collected from the epididymal caput. There were more than $14 \%$ more spermatozoa with head changes located in the epididymal caput than in the epididymal cauda $(P \leq 0.05)$. The semen collected from the cauda of the epididymis showed significantly more sperm cells with tail changes than in the remaining parts of the epididymis. As semen moved through the individual segments of the epididymis, the proportion of spermatozoa with head changes and cytoplasmic droplets decreased, while the proportion of spermatozoa with tail changes increased.
\end{abstract}

Key words: sperm morphology, canine, epididymis.

\section{INTRODUCTION}

Semen morphology assessment provides information about the quality of ejaculate and allows to determine the forms of abnormal sperm structure, which may reduce the fertilizing capacity of semen. It consists of determining the incidence of morphological changes in spermatozoa and indicating the type of deformities found. Sperm morphology examination is often the main criterion for assessing male semen of various species of animals used in insemination (Kondracki et al. 2012; Banaszewska et al. 2015; Górski et al. 2017). The results of such examination provide information about the course of spermatogenesis and about changes in the morphology of spermatozoa, occurring after the development of gametes, mainly during the maturation process in the epididymis. Semen collected through ejaculation is often used

Corresponding author: Anna Wysokińska, Siedlce University of Natural Sciences and Humanities, Faculty of Agrobioengineering and Animal Husbandry, Bolesława Prusa 14, 08-110 Siedlce, e-mail: anna.wysokinska@uph.edu.pl, ORCID: 0000-0003-2654-3604. 
in dog reproduction. Increasing incidence of reproductive disorders in sire dogs, which are valuable for breeding, makes it necessary to search for other methods of semen collection. Alternatively, semen may be collected from male epididymis ex vivo or in vivo (Luvoni and Morselli 2017). Canine spermatozoa often have specific characteristics distinguishing them from spermatozoa of other mammalian species. Understanding the structure and functioning of spermatozoa passing through individual sections of the epididymis can help develop better and more effective sperm cryopreservation methods and assisted reproductive techniques for subjects undergoing castration.

The aim of the study was to analyze the incidence of spermatozoa with morphological changes, found in the semen collected from the caput, corpus and cauda of canine epididymis.

\section{MATERIAL AND METHODS}

The study was conducted on five healthy dogs aged 3 to 8 years, from which gonads were obtained as a result of routine castration performed in a veterinary clinic. Gonads were placed in a $0.9 \% \mathrm{NaCl}$ solution and transported to the laboratory, where further tests were performed. After rinsing with PBS fluid, epididymides were isolated and divided into three sections: caput, corpus and cauda. Semen was collected by incising the individual parts of the epididymis on separate Petri dishes. Microscopic preparations for the assessment of sperm morphology were made from the collected semen. The preparations were stained with the SpermBlue method (Van der Horst and Maree 2009). The sperm morphology was assessed using a 100x immersion lens with a Nikon E-50i light microscope. In each preparation, the morphological structure of 200 sperm cells was assessed, specifying the spermatozoa with normal structure and showing morphological changes according to Blom classification (Blom 1981). A total of 3000 spermatozoa were analyzed. Morphological changes in spermatozoa were grouped into sperm cells with major changes, and spermatozoa with minor changes. Additionally, in terms of morphological changes, sperm cells with changes in their head, tails and those with cytoplasmic droplets were distinguished, respectively (Fig. 1).

The obtained results were processed statistically using the variance analysis method with the Statistica $v 13.1$ software. The significance of intergroup differences was based on the Tukey test at $\mathrm{P} \leq 0.05$.

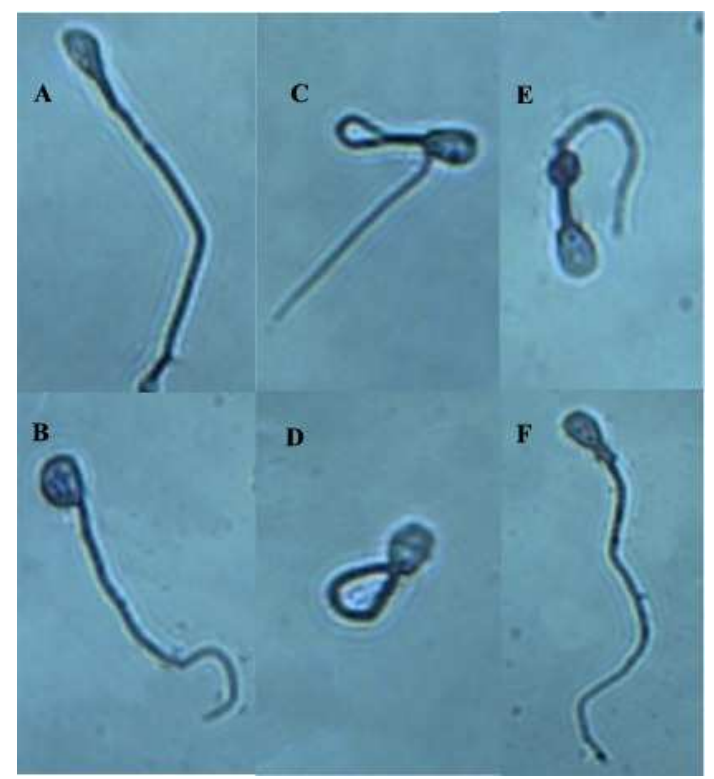

Fig. 1. Selected morphological changes in spermatozoa observed in the canine epididymis: A - spermatozoa with head narrow at base, $B$ - spermatozoa with head abnormal contour, C - spermatozoa with simple bent tail, D - Dag-defect, E - spermatozoa with distal droplet, $\mathrm{F}$ - spermatozoa with pseudodroplet 


\section{RESULTS AND DISCUSSION}

Based on the data summarized in Table 1, it appears that there are differences in the incidence of spermatozoa with morphological changes in individual sections of the epididymis. The largest share of spermatozoa with normal morphological structure was demonstrated within the corpus of the epididymis. About $36 \%$ of spermatozoa with normal structure were found in this part of the epididymis, i.e. over $5 \%$ more than in the epididymal caput and over $13 \%$ more than in the epididymal cauda $(P \leq 0.05)$. The share of spermatozoa with major changes in the caput and corpus of the epididymis was similar (about 18\%) and higher by more than $6 \%$ than in the epididymal cauda $(P \leq 0.05)$. Slightly different observations were reported by Varesi et al. (2013 a, b) in their study, finding a higher percentage of spermatozoa with normal morphology in the epididymal cauda than in the epididymal caput. In this study, a smaller share of sperm cells with normal structure found in the tail of the epididymis was affected by demonstrated high percentage of sperm cells with minor changes. The proportion of spermatozoa with morphological changes varies during the maturation process taking place in the epididymis. During the passage of spermatozoa through the successive anatomical sections of the epididymis, gametes undergo numerous changes, e.g. they acquire the ability to move (Varesi et al. 2013 b), and the cytoplasmic droplet migrates along the sperm from the proximal segment of the midpiece to the back of the sperm (Axner et al. 2004; Cooper 2011).

Table 1. The share of spermatozoa with normal morphological structure and those with major and minor changes in canine epididymis (mean $\pm S D$ )

\begin{tabular}{lccc}
\hline \multirow{2}{*}{ Item } & \multicolumn{3}{c}{ Part of the epididymis } \\
\cline { 2 - 4 } & caput & corpus & cauda \\
\hline $\begin{array}{l}\text { Spermatozoa with } \\
\text { normal morphology }\end{array}$ & $30.43^{\mathrm{a}} \pm 20.12$ & $35.86^{\mathrm{b}} \pm 13.07$ & $22.44^{\mathrm{c}} \pm 11.42$ \\
\hline $\begin{array}{l}\text { Spermatozoa with major } \\
\text { changes }\end{array}$ & $18.56^{\mathrm{a}} \pm 8.53$ & $18.46^{\mathrm{a}} \pm 8.16$ & $12.22^{\mathrm{b}} \pm 3.39$ \\
\hline $\begin{array}{l}\text { Spermatozoa with minor } \\
\text { changes }\end{array}$ & $50.98^{\mathrm{a}} \pm 15.97$ & $45.71^{\mathrm{b}} \pm 17.46$ & $66.02^{\mathrm{c}} \pm 14.10$ \\
\hline
\end{tabular}

a,b,c Values in lines marked with different letters differ significantly at $P \leq 0.05$.

The analysis of sperm morphology showed that the highest number of spermatozoa with head changes and cytoplasmic droplets is present in semen collected from the caput of the epididymis (Table 2). There were over $14 \%$ more spermatozoa with head changes found in the epididymal caput than in the epididymal cauda $(P \leq 0.05)$. The semen collected from the cauda of the epididymis showed significantly more sperm cells with tail changes than in the remaining parts of the epididymis. Some studies show that the share of spermatozoa with tail changes is greater within the corpus than in the caput or cauda of the epididymis (Varesi et al. $2013 \mathrm{a}, \mathrm{b}$ ). In the studies presented in this paper, it was found that the proportion of spermatozoa with cytoplasmic droplets decreased with semen moving through the individual sections of the epididymis. The presence of spermatozoa with a closer cytoplasmic droplet in ejaculates of dogs and other animal species is a sign of abnormal sperm maturation, which may cause biochemical disturbances interfering with the normal course of capacitation (Pena et al. 2007). It was shown that spermatozoa with a closer cytoplasmic droplet show poor adhesion to the zona pellucida of the oocyte (Pena et al. 2007). 
Table 2. Proportion of sperm cells with changes in heads, tails and those with cytoplasmic droplets in canine epididymis (mean $\pm \mathrm{SD}$ )

\begin{tabular}{lccc}
\hline \multirow{2}{*}{ Item } & \multicolumn{3}{c}{ Part of the epididymis } \\
\cline { 2 - 4 } & caput & corpus & cauda \\
\hline $\begin{array}{l}\text { Spermatozoa with head } \\
\text { chages }\end{array}$ & $36.16^{\mathrm{a}} \pm 11.19$ & $23.24^{\mathrm{b}} \pm 4.87$ & $21.49^{\mathrm{b}} \pm 9.88$ \\
\hline $\begin{array}{l}\text { Spermatozoa with tails } \\
\text { changes }\end{array}$ & $31.47^{\mathrm{a}} \pm 12.84$ & $40.56^{\mathrm{b}} \pm 19.08$ & $58.51^{\mathrm{c}} \pm 15.41$ \\
\hline $\begin{array}{l}\text { Spermatozoa with } \\
\text { cytoplasmic droplets }\end{array}$ & $1.92^{\mathrm{a}} \pm 1.15$ & $0.76^{\mathrm{b}} \pm 0.23$ & $0.25^{\mathrm{b}} \pm 0.27$ \\
\hline
\end{tabular}

a,b,c Values in lines marked with different letters differ significantly at $P \leq 0.05$

The studies presented in Table 2 showed that the share of spermatozoa with cytoplasmic droplets in individual parts of the epididymis was relatively small and amounted to about $2 \%$ in the epididymal caput and $0.25 \%$ in the epididymal cauda. Some studies have shown that an error in cytoplasmic droplet translocation within a sperm cell's tail reduces sperm motility (Cooper 2005; Xu et al. 2013). The relationship between the presence of spermatozoa with cytoplasmic droplet and their motility may depend on several typical characteristics of cytoplasmic droplet, such as: unique composition of lipids, RNAs, lipoproteins and hydrolytic enzymes (Cooper and Yeung 2003; Rengan et al. 2012).

Analyzing the changes in the morphological structure of spermatozoa that occur during semen transport through the epididymis may suggest that the organism tries to get rid of morphologically defective male gametes. This possibility was confirmed in studies by Axner (2006), who proved that the number of spermatozoa with morphological changes decreases as semen moves from the epididymal caput to the epididymal cauda. Such a tendency was found in our research in case of spermatozoa with head changes and cytoplasmic droplets.

\section{CONCLUSIONS}

In conclusion, it should be stated that the incidence of spermatozoa with normal morphological structure and changes in heads and tails, as well as those with cytoplasmic droplets, varies depending on the segment of the epididymal duct. As semen moved through the individual segments of the epididymis, the proportion of spermatozoa with head changes and cytoplasmic droplets decreased, while the proportion of spermatozoa with tail changes increased. Sperm cells collected mainly from the epididymis show the best suitability for use in the reproduction of dogs, because of the highest proportion of spermatozoa with normal morphological structure shown in this section.

\section{ACKNOWLEDGMENT}

Research was financed by Siedlce University of Natural Sciences and Humanities as a part of statutory activity. 


\title{
REFERENCES
}

Axner E. 2006. Sperm maturation in the domestic cat. Theriogenology 66, 14-24.

Axner E., Hermansson U., Linde-Forsberg C. 2004. The effect of Equex STM paste and sperm morphology on post-thaw survival of cat epididymal spermatozoa. Anim. Reprod. Sci. 84, 179-191.

Banaszewska D., Biesiada-Drzazga B., Andraszek K. 2015. Frequency of Cytoplasmic Droplets Depends on the Breed and Age of Insemination Boars. Folia Biol. 63, 9-18.

Blom E. 1981. Morphological defects in sperm bull II. Proposed new classification of defects in sperm. Med. Wet. 37, 239-242.

Cooper T.G. 2005. Cytoplasmic droplets: the good, the bad or just confusing? Hum. Reprod. 20(1), 9-11.

Cooper T.G. 2011. The epididymis, cytoplasmic droplets and male fertility. Asian J. Androl. 13(1), 130-138.

Cooper T.G., Yeung C.H. 2003. Acquisition of volume regulatory response of sperm upon maturation in the epididymis and the role of the cytoplasmic droplet. Microsc. Res. Tech. 61, 28-38.

Górski K., Kondracki S., Wysokińska A. 2017. Inter- and intra-breed variation in ejaculate characteristics and in the morphology, dimensions and shape of spermatozoa of boars used for artificial insemination. Folia Pomer. Univ. Technol. Stetin., Agric., Aliment., Pisc., Zootech. 3, 41-52.

Kondracki S., Iwanina M., Wysokińska A., Huszno M. 2012. Comparative analysis of Duroc and Pietrain boar sperm morphology. Acta Vet. Brno 81(2), 195-199.

Luvoni G.C., Morselli M.G. 2017. Canine epididymal spermatozoa: A hidden treasure with grea potential. Reprod. Dom. Anim. 52, 197-201.

Pena A.I., Barrio M., Becerra J.J., Quintela L.A., Herradon P.G. 2007. Infertility in a dog due to proximal cytoplasmic droplets in the ejaculate: investigation of the significance for sperm functionality in vitro. Reprod. Dom. Anim. 42(5), 471-478.

Rengan A.K., Agarwal A., Linde M. van der, Plessis S.S. du. 2012. An investigation of excess residual cytoplasm in human spermatozoa and its distinction from the cytoplasmic droplet. Reprod. Biol. Endocrin. 10, 1-8.

Varesi S., Vernocchi V., Faustini M., Luvoni G.C. 2013a. Morphological and acrosomal changes of canine spermatozoa during epididymal transit. Acta Vet. Scand. 55, 17-22.

Varesi S., Vernocchi V., Faustini M., Luvoni G.C. 2013b. Quality of canine spermatozoa retrieved by percutaneous epididymal sperm aspiration. J. Small Anim. Pract. 54, 87-91.

Xu H., Yuan S.Q., Zheng Z.H., Yan W. 2013. The cytoplasmic droplet may be indicative of sperm motility and normal spermiogenesis. Asian J. Androl. 15, 799-805.

\section{CZĘSTOŚĆ WYSTĘPOWANIA PLEMNIKÓW ZE ZMIANAMI MORFOLOGICZNYMI W NASIENIU POBRANYM Z NAJĄDRZY PSÓW}

\begin{abstract}
Streszczenie. Celem badań była analiza występowania plemników ze zmianami morfologicznymi w nasieniu pobieranym z najądrzy psów. Badania przeprowadzono na pięciu psach, od których pozyskano gonady w wyniku rutynowej kastracji wykonanej w przychodni weterynaryjnej. Po opłukaniu gonad płynem PBS wyizolowano najądrza. Nasienie pobierano przez nacinanie jałowym skalpelem poszczególnych części najądrza (głowy, trzonu, ogona) umieszczonych na oddzielnych szalkach Petriego. Z tak pobranego nasienia wykonano preparaty do oceny morfologii plemników. Preparaty barwiono metodą SpermBlue. Ocenę morfologii plemników przeprowadzono przy użyciu obiektywu immersyjnego, przy powiększeniu 100-krotnym, z wykorzystaniem mikroskopu świetlnego Nikon E-50i. W każdym preparacie oceniono budowę morfologiczną 200 plemników, wyszczególniając plemniki o prawidłowej budowie morfologicznej oraz ze zmianami główek, ze zmianami witek i z kroplami cytoplazmatycznymi. Na podstawie przeprowadzonych badań stwierdzono różnice w częstości występowania plemników ze zmianami morfologicznymi w poszczególnych odcinkach przewodu najądrza. W obrębie trzonu najądrza zaobserwowano największy udział plemników o prawidłowej budowie morfologicznej.
\end{abstract}


Najwięcej plemników ze zmianami główek i z kroplami cytoplazmatycznymi stwierdzono w nasieniu pobieranym z głowy najądrza. W głowie najądrza było o ponad $14 \%$ więcej plemników ze zmianami główek niż w ogonie najądrza $(P \leq 0,05)$. W nasieniu pobieranym z ogona najądrza wykazano istotnie więcej plemników ze zmianami witek niż w pozostałych odcinkach przewodu najądrza. Wraz z przesuwaniem się nasienia przez poszczególne odcinki przewodu najądrza zmniejszał się udział plemników ze zmianami główek i z kroplami cytoplazmatycznymi, natomiast zwiększał się udział plemników ze zmianami witek.

Słowa kluczowe: morfologia plemnika, pies, najądrze. 